\title{
Chapter 10 \\ Labour Migration and other Forms of Mobility Between Bulgaria and Greece: The Evolution of a Cross-Border Migration System
}

\author{
Panos Hatziprokopiou and Eugenia Markova
}

This chapter presents an overview of the Greek-Bulgarian migration system, focusing particularly on aspects of Bulgarian migration to Greece. Although largely empirical, the account is set within the broader transnational context of mobility between the two countries. This appears to be shaped primarily by geographical proximity and is dominated by labour migration from Bulgaria to Greece. However, it is also increasingly characterized by a constant 'back-and-forth' movement of people, as well as of goods, services, and money - in both directions. A turning -point in the evolution of this context has been Bulgaria's EU accession in 2007, which liberalized mobility - potentially diverting the course of population flows towards more advanced European countries - while also reconfiguring not only Bulgaria's but also Greece's borders and geographical position in both the Balkans and Europe. Indeed, for the first time Greece is now connected to the EU by land. Within this context, the chapter explores Bulgarian-Greek migration patterns and other cross-border movements and investigates the relevance of circular migration and its developmental potential. Thus, the Greek-Bulgarian case could be evaluated in the light of recent developments in academic and policy discourses on the benefits of circular migration. ${ }^{1}$

\footnotetext{
${ }^{1}$ For an overview of the concept, experiences and policy implications of circular migration see, e.g., Bieckmann and Muskens (2007), Vertovec (2007), Fargues (2008), and Maroukis and Gemi (2010).
}

\footnotetext{
P. Hatziprokopiou $(\bowtie)$

Department of Spatial Planning and Development,

Aristotle University of Thessaloniki, Thessaloniki, Greece

e-mail: panoshatziprokopiou@hotmail.com

E. Markova

The Faculty of Business and Law,

London Metropolitan University, London, United Kingdom

e-mail: E.Markova@londonmet.ac.uk

(C) The Author(s) 2015. This book is published with open access at SpringerLink.com

H. Vermeulen et al. (eds.), Migration in the Southern Balkans, IMISCOE Research Series,

DOI 10.1007/978-3-319-13719-3_10
} 
The chapter draws on the authors' previous research on Bulgarian migrants in Greece, ${ }^{2}$ revisited in the light of official statistics from various sources: the 2001 Greek census, residence permit data from the Greek Ministry of Interior, labour force surveys, marriage and birth registers, international trade and tourism data from the Greek Statistical Authority, Greek police statistics, and data on migration and travel from the Bulgarian Statistical Institute. Where appropriate, the analysis is further supported with 'grey material' such as press articles and Internet resources. It furthermore offers a perspective 'from the ground' derived from four in-depth interviews with Bulgarian informants in Athens conducted in the summer of $2011 .^{3}$ The chapter begins with an account of the evolution of migratory flows between Bulgaria and Greece since 1989. It then examines aspects of Bulgarian immigrants' social incorporation in Greece, with a focus on their position in the labour market. Finally, it explores other forms of mobility and types of flow, suggesting a shift from a unidirectional labour migration system towards a broader context of transnational mobility in the new Balkans.

\subsection{Migration Dynamics Between Bulgaria and Greece}

The collapse of Bulgaria's centrally planned system amidst the turmoil in Eastern Europe and the Soviet Union at the end of the 1980s expectedly produced outward population movements. The only movement that could be described as a mass exodus, however, was that of Turkophone Bulgarian Muslims, who left early on, heading mainly to Turkey (see İçduygu \& Sert and Parla, both in this volume). There was also minor but steady emigration of highly skilled professionals towards Western Europe and North America which continued for most of the 1990s (Markova and Sarris 1997; Chompalov 2000) up to today (Glytsos 2010). Nonetheless, there is no consensus regarding the extent to which this constituted significant brain drain (Bagatelas and Kubicová 2003). At the same time, political instability and corruption, coupled with economic hardship, unemployment, and low pay drove many Bulgarians to seek employment abroad. According to data from the Bulgarian National Statistical Institute (Stanchev 2005, p. 15), the numbers of Bulgarians

\footnotetext{
${ }^{2}$ The second author, Eugenia Markova conducted two quantitative studies (mainly) in Athens, one in 1996 based on a sample survey of 100 undocumented migrants and the second one in 1999 which questioned 153 recently legalized and undocumented Bulgarians (Markova 2001; Markova \& Sarris 1997, 2002a, 2002b; Sarris and Markova 2001). She also conducted a qualitative study of Bulgarians on the island of Rhodes using a sample of 58 persons (Markova 2009). The first author, Panos Hatziprokopiou included a sample of 70 Bulgarian immigrants in his research in Thessaloniki in 2001 and 2002 (Hatziprokopiou 2004, 2006).

${ }^{3}$ The authors conducted four interviews with (i) a woman involved in the Bulgarian community who had worked in a Greek state programme offering information and legal support to migrants (SDz, 18 July 2011), (ii) the director of the largest supplementary Bulgarian school in Athens (D, 22 July 2011), (iii) an employee in a Bulgarian coach company (UI, 25 July 2011), and (iv) a Bulgarian entrepreneur owning three businesses in central Athens (BE, 26 July2011).
} 
travelling abroad picked up in the early 1990s, then dropped considerably, increased in 1997, then declined again before increasing anew after 2000. Principal destinations were Turkey, Greece, Spain, Germany, Italy, and ultimately the UK, with the picture diversifying in the 2000s (Markova 2009, 2010; Markova and Black 2007). These movements have become even more pronounced since the country's EU accession in 2007, which initiated a broader scope of population mobility. At the same time, Bulgaria has started to become a country of transit as well as a receiving state for non-European migrants.

Greece emerged as a key destination for Bulgarian migrants from the very beginning. In contrast to Hoxha's isolated Albania, where the vast majority of Greece's immigrants come from (see, e.g., Vullnetari in this volume), the Iron Curtain was not entirely impenetrable in the Bulgarian case. Even before the 1990s, there was some degree of population mobility, concerning mostly Greek students in Bulgaria and partnerships resulting in mixed marriages, as well as professionals (scientists, artists and sportspeople) who had migrated to Greece before 1989 (Hatziprokopiou 2006, Chap. 4). At the same time, Greece was host to one of the largest communities of Bulgarian political refugees (Guentcheva et al. 2003), while Bulgaria had accepted about 7,000 refugees from Greece (SOPEMI 1993, p. 112) following the end of the Greek Civil War in 1949, of whom 4,500 remained in the country (see editors' introduction to this volume). Subsequently, the migration patterns between the two countries evolved in four stages (Nikolova 2010): (i) from 1989-1996 the dominant pattern was one of seasonal migrations ${ }^{4}$ and undocumented border crossings; (ii) the period from 1997 to 2001 was marked by the severe political and economic crisis facing Bulgaria, but also by the first regularization programmes for immigrants in Greece; (iii) the period between 2001 and 2007, marked by the abolition of visa requirements for Bulgarians travelling in the Schengen area, as well as the maturation of immigrant communities in Greece; and (iv) the period from 2007 onwards, in which mobility patterns started to develop in the context of Bulgaria's EU accession.

Geographical proximity and relative ease of entry have largely conditioned Bulgarian migration to Greece since the beginning of the 1990s (Hatziprokopiou 2004, 2006; Angelidou 2008), perhaps more as a matter of necessity and convenience than as an ideal destination. In two International Organization for Migration (IOM) surveys, Greece featured in Bulgarians' intentions to work abroad temporarily rather than permanently, involving thereby the potential of circularity (Guentcheva et al. 2003, pp. 25-26). Greece was the second preferred destination in 1996 and the third in 2001, constituting 13 and $6.8 \%$ respectively of the respondents' preferences regarding employment abroad 'for a couple of months' (following the USA and Germany). However, it does not appear in the eleven most favoured permanent destinations in the 1996 survey and is at only sixth place for just $2.4 \%$ of the respondents in the 2001 survey. In the words of SDz, one of the female interviewees:

\footnotetext{
${ }^{4}$ According to unofficial data from the Bulgarian Ministry of Interior, some 33,000 Bulgarian citizens migrated to Greece in 1990 as seasonal farm workers (Markova 2001, p. 11)
} 
Bulgarians chose Greece as a country to work in because it is the closest EU country....

They think they can return more easily and quickly to their families.

However, the benefits of proximity could not be fully enjoyed during the early phase (until 1998) due to the restrictive legal framework that characterized Greek immigration policy, leaving thousands of people without any opportunity to legalize their status. The majority had either crossed the newly opened border illegally, or travelled on individual or group tourist visas - and, in some cases, business visas - which they subsequently overstayed. In a survey of Bulgarian migrants in Thessaloniki in 2001-2002, one quarter of the sample (mostly early arrivals) had crossed illegally, while another $43 \%$ (mostly women) had arrived on a tourist visa (Hatziprokopiou 2006, pp. 98-100). Among the former, some were smuggled into Greece over the mountains, paying € 200-300 in 1997 (in German marks or US dollars). ${ }^{5}$ As put by another interviewee:

I had no papers; I came illegally, like everybody. There were no papers back then; all of us were without papers (BE).

Yet, mobility in this early stage was not entirely hindered, since migration projects were still quasi-experimental and followed largely temporary patterns of seasonal work in agriculture, tourism, and catering - especially from border regions to various places in northern Greece. It was the common experience of many, especially those who did have work back home, to come for a short period of employment initially and then go back again before taking the decision to settle in Greece for longer. A bilateral agreement on seasonal migration signed between the two countries in $1996^{6}$ came to encompass these predominantly temporary early patterns, but was never put into general practice. More pronounced cyclical routes can be observed in the case of ethnic Greek Bulgarians (Sarakatsani) from various places on the southern slopes of the long mountainous line from Plovdiv to Sliven. Benefiting from a special legal status offering them temporary visas, they were able to combine cattle-breeding activities in Bulgaria with seasonal work in northern Greece (Hatziprokopiou 2006). Conversely, the predominantly female migration flows to Athens in the 1990s had a more permanent character, based on employment opportunities in child and elderly care in private households. In fact, independent female migration has been a chief characteristic of Bulgarian migration to Greece (see Van Boeschoten in this volume).

In general, the restrictive policy framework kept migrants in a limbo of life ambiguity and legal vulnerability, significantly restricting circular mobility. When economic uncertainty escalated with the 1997 crisis in Bulgaria, which led many factories to close, especially in the northern part of the country, ${ }^{7}$ going back even

\footnotetext{
${ }^{5}$ Some $27 \%$ of the sample in Thessaloniki was comprised of Bulgarian nationals of ethnic Greek origin (Sarakatsani), and about 6\% had arrived after the liberalization of entry in April 2001 (Hatziprokopiou 2006).

${ }^{6}$ Law No 2407 of 4 June 1996 (Greek Government Gazette 103)

${ }^{7}$ The majority of early immigrants in Athens originated from large northern Bulgarian cities that were hit by the industrial decline of the 1990s; those arriving after 2000 came from a variety of
} 
temporarily was not an option. Patterns of mobility became more fixed and unidirectional, from Bulgaria to Greece, even excluding in some cases the possibility of short visits back home for social or family reasons:

When you don't have documents and you don't have the way open to go home you cannot return, these were very difficult years for Bulgarians. I remember cases when parents have died or there were ill persons in the family and we could not go back, because we would not be able to return here $(\mathrm{SDz})$.

Other examples included mothers unable to travel back to see their children, who were very young or of school age and usually left behind in the care of grandparents or other close relatives until they completed a school cycle in Bulgaria or graduated. This reveals one of the most profound social effects of emigration, determined by restrictive immigration regimes - that is, changes in family composition and child outcomes in terms of health and education. The former occur when either one partner emigrates - which often leads to a break-up - or when both partners emigrate and the children are left behind. Transnational family arrangements take complex forms. For example, a Bulgarian man in Athens, involved in circular migration to Greece, reported having families in both countries:

I have a home here and there; I have a wife in Bulgaria and two children; now, I have a partner and a child in Greece as well (Markova 2010, p. 16).

With the initiation of the first state regularization scheme in 1998, which launched a two-stage legalization process initially granting immigrants a temporary 'white card', entry and especially stay became more institutionalized towards the end of the decade. Problems of movement such as those described above went on even after regularization, mostly because of the bureaucracy of the Greek administration which produced extended delays in the issuing of residence permits, often becoming available shortly before they expired (or even after expiry). Overall though, the opportunity to reside legally in Greece signalled a major shift, stimulating feelings of security that gradually contributed towards longer-term migration projects, including family reunion and the migration of entire families with their children. For many, being legal acquired a symbolic form: 'I am not scared any more to talk in Bulgarian in public' (Monastiriotis and Markova 2009, pp. 50-51). In total, some 25,168 Bulgarian immigrants applied for regularization during the first stage of the 1998 scheme, making up a share of $6.8 \%$ of the total number of applicants - the second most numerous nationality among migrants in Greece.

This remained so at the time of the 2001 census, which recorded some 35,104 Bulgarians $-4.6 \%$ of the total. The share of women among Bulgarian immigrants was one of the largest (over $60 \%$ ) among the principal nationalities, confirming the independent character of Bulgarian female migration. Moreover, in contrast to the 'typical' age composition of other immigrant groups in Greece (i.e., marked by overwhelming proportions of younger people), only about a quarter of Bulgarians recorded in the census were 20-29 years old, while another $37.3 \%$ belonged

places across Bulgaria, including Sofia and the South (Markova 2001, 2009; Hatziprokopiou 2006, pp. 90-91). 
to the 30-44 age group, and nearly $23 \%$ were $45-64$ years of age. In addition, the geographical dispersion of Bulgarians' settlements were somehow different in comparison with the distribution of the migrant population as a whole. Although, as expected, higher shares are found in and around the two major urban centres, Bulgarian migrants living in Attica and Greater Athens were proportionally fewer, while significant shares had settled in Crete, Central and Western Greece, and nearly one fifth in the Peloponnese - partly reflecting the relatively large proportion working in agriculture at the time (see next section). Local concentrations are also interesting to note, since the relative weight of Bulgarians among the migrant population in those regions, as well as in north-eastern Greece, is comparably high.

As of April 2001, EU regulations in view of Bulgaria's forthcoming accession granted Bulgarian nationals the right to travel visa-free within the Schengen area. Although this may have stimulated outward mobility from Bulgaria, it does not seem to have substantially changed the lives of immigrants in Greece, partly because border authorities continued to apply strict controls on entry. Such was the experience of $\mathrm{D}$, one of the interviewees, who was refused entry when she first migrated in 2002 'because they didn't let us in'. She was therefore forced to travel through Italy and then enter Greece by boat from Venice to Patras, as border controls on the Greek-Italian (Schengen) border were more relaxed. She then repeated the trip this way four times until 2007 in order to visit her son whom she had left with her parents in Silistra. Or, as another interviewee reported, the abolition of visa requirements 'certainly changed things', but:

[F]or Bulgarian citizens it brought free movement only, but when you are a migrant you need to have a residence permit, so you still could not do anything without the permit. This was more helpful for Bulgarians who were in Bulgaria and needed to come here... for vacation or to visit someone $(\mathrm{SDz})$.

This is confirmed by statistics on the actual number of Bulgarian nationals travelling to Greece at the time, which doubled from about 200,000 people in 2000 to more than 400,000 in 2001 (Stanchev 2005, p. 16). Despite the initial hesitation of Greek border officials to allow entry (in contradiction to the EU regulation, as suggested by the interviewee's experience above), these figures may include some cyclical and seasonal migratory movements, but it is near-impossible to assess their extent. After all, although movement as such was liberalized, residence in Greece remained restricted and penalized. Over the period 2000-2006, an annual average of 2,950 Bulgarians were apprehended and faced deportation (Maroukis 2008, p. 68, Table 18).

Far more significant in providing relative ease of movement, alongside legal security, was the possession of a residence permit, which became a possibility with the first regularization programme in 1998 and was extended in the 2000s with two subsequent schemes taking place in 2001 and 2005- following respective revisions in the immigration policy framework. Figure 10.1 suggests that Bulgarian nationals maintained their second place among immigrants in Greece, despite fluctuations in both absolute numbers and shares. ${ }^{8}$ Their shares actually decreased: from $10 \%$

\footnotetext{
${ }^{8}$ Data for 2004-2006 were kindly provided by Martin Baldwin-Edwards; 2007 data were obtained from the NGO Antigone (www.antigone.gr/stats/default.html, accessed February 2010); 2008 data
} 


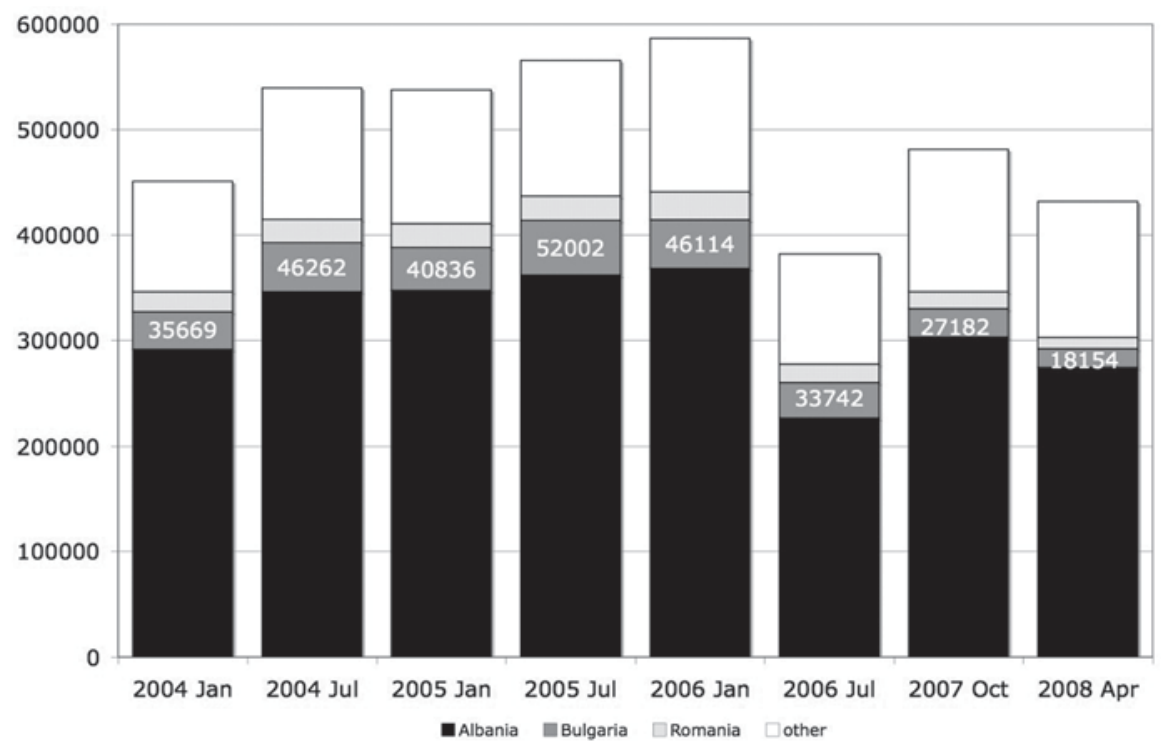

Fig. 10.1 Number of residence permits by country of citizenship, 2004-2008. (Source: Ministry of Interior, Residence Permit Statistics; various years)

in 2003, they comprised 8.4 of all permit holders in 2005 (on average), $5.6 \%$ in 2007 and $4.2 \%$ in 2008. Absolute numbers picked in July 2005, when over 52,000 Bulgarians had a permit to stay, and significantly decreased thereafter in the face of Bulgaria's EU accession.

Detailed data for October 2007 reveal interesting features: among the 27,182 Bulgarian permit holders, about half were older than 40 years of age and another $44.3 \%$ were $18-40$ years of age. Nearly two thirds had a permit for waged work (compared to $59 \%$ of the total migrant stock), some $19 \%$ had a permit given to spouses of EU citizens, and we assume that these concern mostly Bulgarians married to Greeks (nearly double the equivalent share among the total). A small but significant proportion (4.6\%) had a permit for seasonal employment, suggesting the importance of circularity in Bulgarian migratory patterns. The share of seasonal work permits among the total was just over $1 \%$, but nearly a quarter of them were issued to Bulgarian nationals. Seasonal migration was regulated by provisions of the 2001 Immigration Bill, according to which employers would state their labour needs by prefecture, basically concerning work in agriculture. Notably, the shares of seasonal residence permits seem to have decreased from about $12 \%$ in 2003-2004, nearly half of which were issued to Bulgarians (Baldwin-Edwards and Apostolatou 2009, p. 251).

are from Maroukis (2008, p. 5, Table 1). We did not have access to more recent data (after 2008), but even if we did these would involve complications as far as Bulgarians are concerned, since they are now EU citizens, with unrestricted mobility, stay and employment since 2009. 
However, circular migratory patterns on a seasonal basis were reported by many migrants in a number of sectors. This did not necessarily involve a seasonal employment permit even when arrangements did take the formal route. Such an example was given by one of the interviewees, based on her family's experience:

My brother, a school teacher [in Bulgaria], for many years has been working with his family at a camping site in Halkidiki... every summer... from June to August they worked here and then they would start the new academic year in Bulgaria (SDz).

Another female interviewee, working for a Bulgarian coach company operating in Greece, confirmed this constant 'back and forth' from the point of view of seasonal traffic in travel between the two countries:

When people have their time off from work here and go on holiday, other people [who have jobs in Bulgaria] come here to replace them for the holiday period and then they go back again. So the 'traffic' increases during the summer months (UI).

Bulgaria's EU membership did not immediately end irregular migration. 'New Europeans' could move freely but had no legal right to live and work in Greece. What Fig. 10.1 may imply is that many may have decided not to apply for or renew their permits, waiting instead for Greece to withdraw restrictions on long-term residence and employment — which took place in 2009. In addition, a separate procedure for registering new EU citizens was set up: along with the 18,154 Bulgarians holding a residence permit in 2008, another 11,805 (22\% of the total) held the special EU citizens' permit. So actual numbers may have increased, and movements definitely increased, facilitated by the new EU context - despite the restrictions. A closer look at the overall migration trends in Bulgaria following accession reveals that net emigration escalated from about 1,400 people in 2007, to nearly 15,730 in 2009 and over 27,700 in 2010 (Table 10.1).

The decline over 2007-2008 may be indicative of an initial hesitation and period of adjustment - on the part of migrants themselves, but also by Greek officials and the bureaucracy of the Greek administration, border officials, and immigration services. Despite the initial problems, however, cross-border mobility is no longer restricted, nor are residence and work in Greece. As explained by the interviewees:

After 2007, movement is without any problem; we constantly go and come back, there are people who come here to work for a few months. There is constant mobility (SDz).

Since we joined the EU, how can I tell you, there are no borders... I have three lorries, they travel to Bulgaria every week. I don't think, for example, that before [2007] there were fewer Bulgarians here and now there are more; basically it's about ease in moving, in coming and going (BE).

Table 10.1 Migration flows to and from Bulgaria, 2007-2009. (Source: National Statistical Institute of Bulgaria, Population Statistics (Migration: Tables 5.7, 5.8))

\begin{tabular}{l|l|l|l|l}
\hline & 2007 & 2008 & 2009 & 2010 \\
\hline Inflows & 1561 & 1236 & 3310 & 3518 \\
\hline Outflows & 2958 & 2112 & 19,039 & 27,708 \\
\hline Net migration & -1397 & -876 & $-15,729$ & $-24,190$ \\
\hline
\end{tabular}


The new era of free movement and employment, however, has been obscured by Greece's unfolding economic crisis over recent years. The patterns of mobility may change anew, considering the emerging trends of migrants leaving Greece for their hometowns in Bulgaria, or even re-emigrating to more economically stable countries. As one female interviewee stated:

\begin{abstract}
Jobs are now fewer, and wages have dropped. For instance, the starting salary for a newcomer woman [in domestic service or care] used to be $€ 600, € 650$, even $€ 700$, now it may be $€ 400 \ldots$ but then again it depends on the market, where you are, the employers, etc.... But there are many Bulgarians who return, either return to Bulgaria or move to other countries... there are cases of families, usually young people, who choose other countries, usually northern countries with a better economy (SDz).
\end{abstract}

Still, however, the consistent job and income disparities between the two countries and the persisting demand for the cheap and flexible work that migrants in Greece perform in sectors and positions still unattractive to the indigenous population, do not suggest a reversal of the Bulgarian-Greek migration regime. Official statistics seem to confirm this picture, at least through the early years of the Greek crisis: preliminary data from the 2011 Census counted 75,915 Bulgarians in Greece; not only their number more than doubled since 2001, but also Bulgarians now formed $8.3 \%$ of Greece's migrant population. According to the same interviewee:

I think that the way things are going Bulgarians will continue to come here for work, even in smaller numbers, because wages in Bulgaria are the lowest among the $27 \mathrm{EU}$ member states. Pensions are very low. So even with this really deep crisis now in Greece... Bulgarians stay in Greece...Immigrants, whether Bulgarians or [other] EU citizens or third country nationals continue to do the 'black' jobs, the difficult ones, because... Greeks many times avoid these jobs, they go for the public sector (SDz).

The current economic climate in Greece may 'push' some migrants back home. Nonetheless, the return is only temporary owing to the limited availability of jobs, and geographic proximity between the two countries facilitates circularity. Another interviewee told us that if someone were without work, he or she may go back for 5 or 6 months and then return again. There is thus the possibility of a proliferation of 'backand-forth' movements. In the double conjuncture of an enlarged EU and Greece's economic crisis, cyclical migration patterns and the maintenance of livelihoods in both countries may become an attractive option to many immigrants. This may furthermore remain so as long as the structural conditions in the Greek labour market reserve a space for immigrant labour, even if this space shrinks in times of crisis. The next section reviews the employment patterns of Bulgarian immigrants, which have largely conditioned their economic and social integration in the past 2 decades.

\title{
10.2 Socio-Economic Incorporation of Bulgarian Immigrants in Greece
}

Migrant employment in Greece since the early 1990s has responded to an increased demand for cheap and flexible labour, partly functioning as a substitute for family workers in small businesses and households (Fakiolas 2003; Hatziprokopiou 
2006; Cavounidis 2006). The demographic ageing of the indigenous population, the continued emptying of the Greek countryside, the growth of the middle classes, the increasing participation of women in the labour market, the link between higher educational attainments and better job prospects for younger generations, along with the size of the informal economy have provided for 'pull factors' for the employment of immigrant labour. Moreover, in a drive for competitiveness, small businesses have adopted cost-cutting strategies in labour-intensive activities via informal economic arrangements. The high seasonality of core economic sectors (e.g., agriculture, construction, and tourism), and the casual character of certain employment niches (e.g., domestic and care work) have favoured these developments.

The employment patterns of Bulgarian immigrants reflect this broader picture, though certain peculiarities may be noted. First, in general, immigrants' employment participation rates are higher than for Greeks, but this rate is even higher for the Bulgarians. Labour force survey data show this averages $84 \%$ between 2005 and the first half of 2011. Secondly, Bulgarians' principal sectors of employment at the time of the 2001 census appeared to be agriculture and 'other services' (comprising nearly $63 \%$, compared to less than $40 \%$ in total immigrant employment), while relatively fewer Bulgarians worked in manufacturing and construction (6.5 and $11 \%$, respectively, compared to about half among all immigrant workers). For women, services such as cleaning, care, and domestic work are important. Nearly half of Bulgarian women were employed in such jobs. Lastly, among Bulgarian immigrants, slightly larger than average shares were employed as skilled or unskilled manual workers $(70.3 \%)$, unqualified service employees $(11.4 \%, 16.7 \%$ among women), and skilled farmers (9.5\%).

The authors' past research suggests that these patterns reflect the structures of local labour markets. For example, employment in agriculture is absent in studies of Bulgarian undocumented and legalized migrants in Athens and Rhodes (Markova 2001, 2009), and features only as past experience in studies of Bulgarian immigrants in Thessaloniki (Hatziprokopiou 2006), while employment in hotels and restaurants is far more significant in Rhodes (Markova 2009). The impact of time has been important, and in this respect the acquisition of legal status has proven to be a decisive factor. Conditions seem to have improved over time, including the migrants' capacity to negotiate their position and pay, or to find more stable and better-paid jobs - not just as a result of acquiring legal status, but also through knowledge of the country's language, familiarity with the local labour market, and embeddedness in wider social networks.

Recent data confirm shifts in Bulgarian migrants' work. Examining how the situation has changed since the 2001 census, we looked at labour force survey data for 2006 and 2011 (Table 10.2). First, employment in agriculture shrunk from about one third in 2001 to less than $16 \%$ in 2006 and to nearly $13 \%$ in 2011 . Secondly, immigrant employment in construction work had increased in 2006 compared to 2001, reflecting both an increased participation of male Bulgarian workers and the intense construction activity in Greece during the first half of the decade (which included the Olympic Games preparations). However, employment in this sector had dropped to just over $7 \%$ by 2011 as a direct outcome of the market's freezing 
Table 10.2 Bulgarian immigrants' employment by sector (percentage share), 2006 and 2011. (Source: Hellenic Statistical Authority, Labour Force Surveys 2006, 2011 (second trimester))

\begin{tabular}{l|c|l|l|l}
\hline & \multicolumn{2}{|l|}{2006} & 2011 & \\
\hline & All immigrants & Bulgarians & All immigrants & Bulgarians \\
\hline Agriculture & 7.0 & 15.8 & 9.8 & 12.9 \\
\hline Mining & 0.3 & 0.5 & 0.1 & 0.0 \\
\hline Manufacturing & 14.1 & 4.7 & 11.2 & 5.1 \\
\hline Energy \& Water & 0.2 & 0 & 0.5 & 0 \\
\hline Construction & 30.4 & 15.6 & 20.8 & 7.1 \\
\hline Trade \& Repair & 8.6 & 3.5 & 13.3 & 4.7 \\
\hline Hotels \& Catering & 10.5 & 9.2 & 12.4 & 15.4 \\
\hline $\begin{array}{l}\text { Transport, storage \& } \\
\text { communications }\end{array}$ & 2.2 & 1.7 & 3.2 & 1.9 \\
\hline $\begin{array}{l}\text { Finance, real estate, } \\
\text { business services }\end{array}$ & 3.7 & 4.8 & 5.7 & 6.7 \\
\hline $\begin{array}{l}\text { Public admin, educa- } \\
\text { tion, health \& welfare }\end{array}$ & 3.9 & 2.7 & 4.1 & 6.0 \\
\hline Other services & 1.9 & 1.1 & 2.3 & 5.3 \\
\hline Services to households & 17.2 & 40.5 & 16.7 & 34.9 \\
\hline
\end{tabular}

due to the crisis. These proportionate losses indicate a shift from such 'typical' sectors of immigrant employment in Greece towards a wide range of service activities. Employment in household services in particular jumped from $30 \%$ in 2001 to more than $40 \%$ in 2006 , but dropped again to $35 \%$ in 2011 , possibly also with the advent of the crisis, as lower middle class households face difficulties in maintaining a regular domestic worker or carer. Employment in the hotel and restaurant sector, which was already quite important for women in 2001, reached $15.4 \%$ in 2011. Employment in other tertiary activities, including business services, education, and welfare was also on the rise (Table 10.2).

There may be a difference between the educational attainments of migrants settling in large urban centres and those located in smaller cities and less urban areas, as Bulgarian migrants in Rhodes appear to have a lower educational level than those in Athens and Thessaloniki (Markova 2009). More recent data from labour force surveys (Table 10.3) show that although fewer Bulgarians have a tertiary education

Table 10.3 Bulgarian immigrants' education profile, percentage share (average 2005-2009). (Source: Hellenic Statistical Authority, Labour Force Surveys 2005-2009 (by trimester))

\begin{tabular}{l|l|l|l}
\hline Education level & Greek nationals & Foreign nationals & Bulgarian nationals \\
\hline Tertiary & 23.3 & 17.0 & 14.2 \\
\hline Secondary & 40.9 & 60.3 & 68.6 \\
\hline Primary & 33.2 & 22.0 & 16.4 \\
\hline No schooling & 2.6 & 0.8 & 0.8 \\
\hline
\end{tabular}




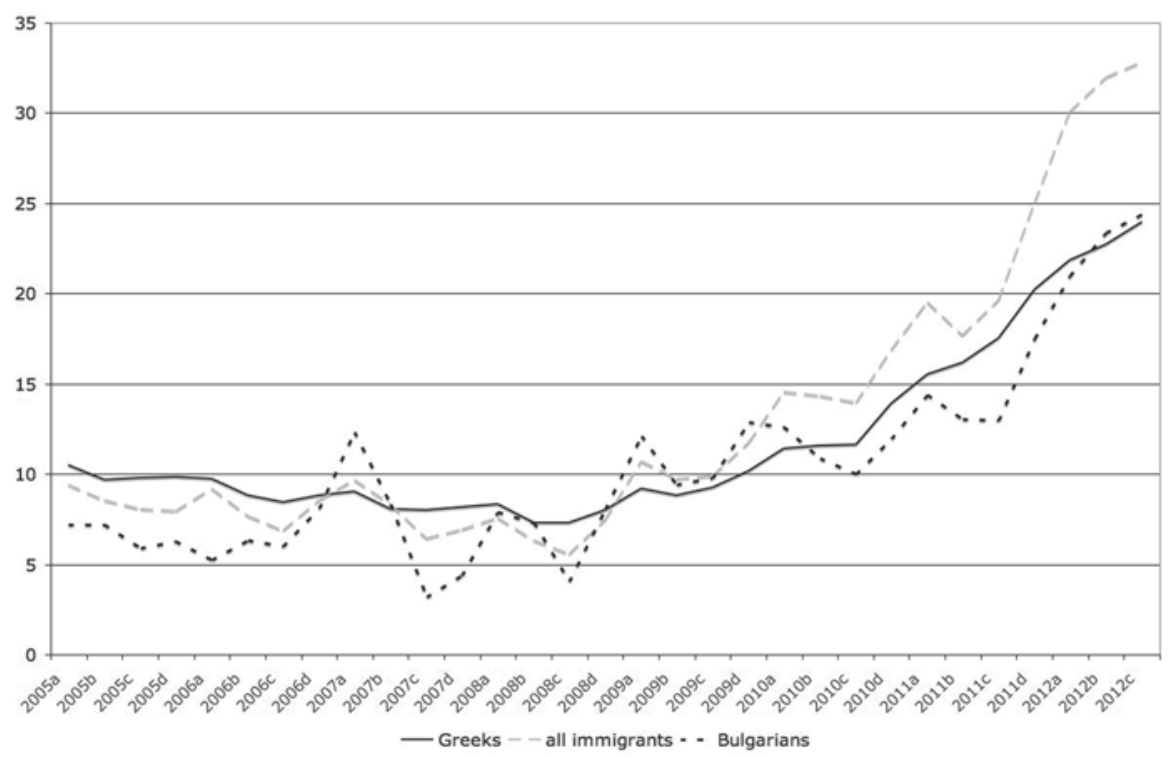

Fig. 10.2 Bulgarian immigrants' unemployment rates, 2005-2012. (Source: Hellenic Statistical Authority, Labour Force Surveys 2005-2012 (by quarter))

compared to Greeks and other foreign nationals, the shares of those without a secondary education are significantly lower. This indicates a relatively good educational level, overall, among the Bulgarian migrants. We can thus speak of deskilling in the process of immigrants' labour market integration, especially at the early stages. Contributing factors to the mismatch between migrants' skills and the work they perform are the problematic transferability of skills and qualifications as well as migrants' limited knowledge of the Greek language. But the chief factor is the structural mechanisms of the Greek labour market.

Unemployment had been uncommon among migrants in Greece until the unfolding of the crisis, with the exception of short periods of moving between jobs. Figure 10.2 shows unemployment rates during 2005-2012. In 2009 immigrants' overall unemployment surpassed that of Greeks for the first time; subsequently, it escalated to nearly $33 \%$ in the second half of 2012. Unemployment among native Greeks rose sharply at the same time. This trend reveals a darker picture for the near future, implying a reversal in the relative improvement of immigrants' labour market position so far. Among Bulgarian immigrants, unemployment rates have been lower that the average among all migrants and among Greeks. The peaks in the winter months are likely largely attributable to the seasonal character of their work.

The trends in immigrants' pay offer further testimony to a relative improvement of conditions over time. But they also reflect a seasonality of employment and some effect of the crisis. Figure 10.3 consists of data provided by IKA, Greece's major insurance fund. ${ }^{9}$ At the end of 2003 the daily wage was $€ 20$, but by June 2010 this had

\footnotetext{
${ }^{9}$ Detailed monthly IKA statistics are available online (www.ika.gr, see «Monthly Employment Statistics») and since 2003 include insured foreign nationals. Official data on earnings obviously
} 


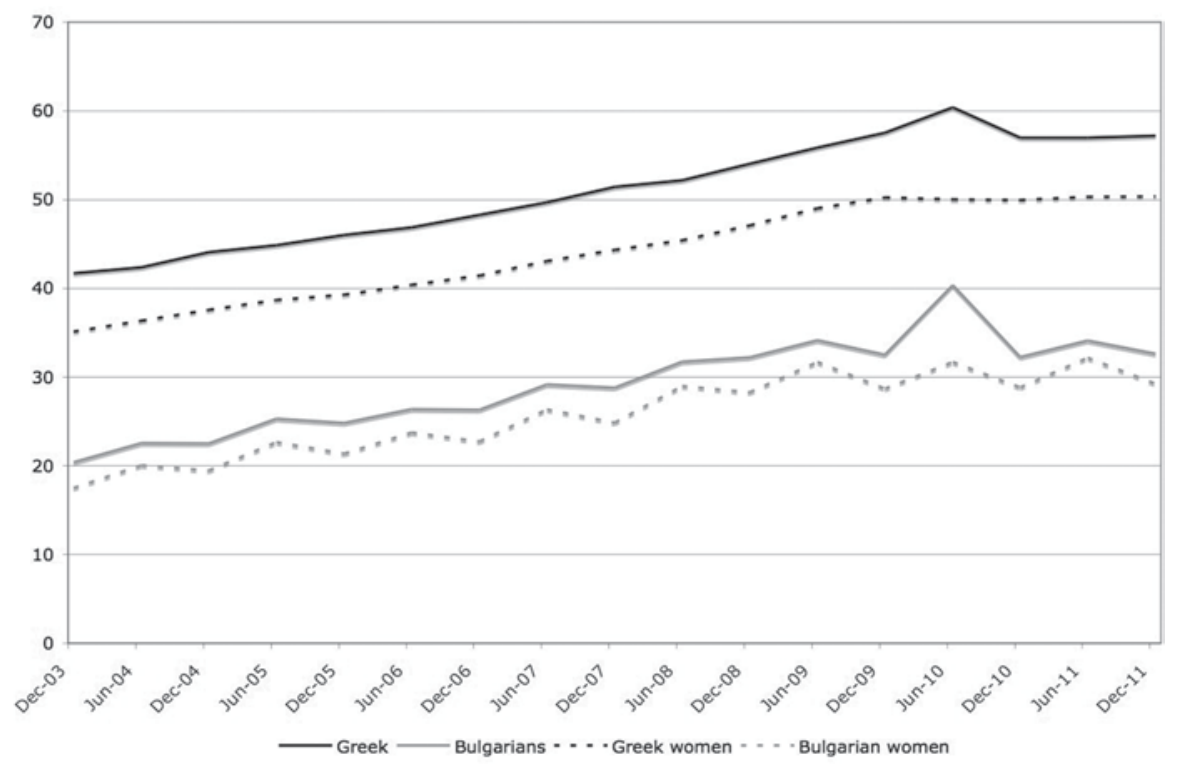

Fig. 10.3 Bulgarian immigrants' daily wages, 2003-2011. (Source: IKA Monthly Statistical Bulletins, December 2003- December 2011, www.ika.gr (accessed 29 January 2013))

doubled. Work experience in both Bulgaria and Greece was found to have a greater - though still weak - effect on earnings, compared to legal status or the migrants' educational level (Markova and Sarris 2002a), as well as the duration of residence in Greece and work in a specific sector or for the same employer (Hatziprokopiou 2006). Any assessment of growth in wages over the last 10 years, however, must also consider the rise of average prices in Greece since the introduction of the euro. With inflation considered earnings were shrinking: Greek citizens' average daily wages dropped from 2010, but for Bulgarians the reduction was about $€ 10$ a day.

Figure 10.3 also shows the persistent gap between Bulgarian migrants' wages and those of Greeks. Despite their steady increase, Bulgarians' daily wages, even at their peak (June 2010), still remained lower than those of Greeks - the difference being $€ 20$. Moreover, there was a marked gender gap, once again with significant differences observed between the earnings of migrant and Greek women. Interestingly, the data show no change owing to Bulgaria's EU accession and the subsequent change in the status of migrants in Greece. On the contrary, Bulgarians appear to be among the least well-paid groups of migrants, though this is mostly due to the large proportion of women, who are among the lowest earners in Greece. At the end of 2010, native IKA-insured Greeks earned on average $€ 57$ a day; Albanian migrants earned $€ 38.50$, Romanians $€ 37.70$, and Pakistanis $€ 37.50$, while Bulgarians earned $€ 32.25$. Bulgarian women were earning less than $€ 28.85$ per day, compared to $€ 49.90$ for Greek and $€ 34.70$ for Albanian women.

concern only people who are insured with the fund, but in our calculations we have not included construction workers. 
An unknown proportion of immigrant workers remained uninsured. Detailed monthly IKA statistics over the period 2004-2010 reveal major fluctuations-reflecting the seasonality of migrants' employment, as many of those insured during winter might pick agricultural produce in the summer months. No change is recorded with Bulgaria's EU accession or the Greek debt crisis. In November 2008, the share of immigrants in informal work was estimated to be about half of the total. ${ }^{10}$ At that time, some 16,666 Bulgarians were insured (about $5 \%$ of the total); the vast majority $(76.1 \%)$ were registered with IKA. If we are to expect that this proportion is representative, we might add the remaining $23.9 \%$ to the IKA figures in order to estimate the total numbers registered with insurance funds. Throughout 2004-2011, the average number of Bulgarians insured on a monthly basis is then 15,174 , which points to an estimated monthly average of 18,795 insured Bulgarian workers in Greece. Taking into account the presence of at least about 30,000 legally resident Bulgarians in the country, this suggests that a high share of Bulgarian migrants remain uninsured.

Considering that the informal economy was a major 'pull factor' throughout the 1990s, most migrants were in unregistered employment and lacked social insurance. Our own research suggests a positive effect of regularization. In a 1996 survey of Bulgarian migrants in Athens, almost the entire sample was undocumented and informally employed; though this was definitely not the case among immigrants surveyed in 1999 (Markova 2001). Among the 2001-2002 sample of Bulgarians in Thessaloniki, about one third were employed informally (Hatziprokopiou 2006, pp. 145-146) though many more reported working irregularly in the past. However, informal or semi-formal employment was also correlated with sector of employment and type of work-for example, nearly half of the women in care and domestic service were uninsured. By 2008, on the island of Rhodes, there was still a stark inconsistency between the migrants' legal status and their employment conditions (Markova 2009; Monastiriotis and Markova 2009). Documented immigrants reported no social insurance coverage; others - desperate to make up for employers not paying social insurance contributions that were compulsory for the renewal of work permits - were either paying the employer's share themselves or were contributing unlawfully to a social fund unrelated to their actual sector of employment. Even some 10 years after legalization, they still did not have equal rights with locals and reported no significant changes in their working conditions after legalization. According to one 32-year-old woman interviewed on the island of Rhodes, 'Employers don't care if you have the right papers; they would always try to save money by paying you less' (Monastiriotis and Markova 2009).

Clearly, there has been a trend towards registered employment and social insurance over time, especially in comparison to the 1990s. Nevertheless, despite improvements with the introduction of regularization programmes, there appears to be a policy paradox regarding legal status and immigrants' employment in Greece. While social insurance was a prerequisite for acquiring legal status, the possession

\footnotetext{
${ }^{10}$ Kathimerini newspaper, 29 November 2008, 'How many migrants can we have?' by M. Delithanasi, p. 18.
} 
of legal status was at the same time a condition for registered employment and therefore also for insurance (as, in principle, the employment of undocumented migrants was prohibited). Given the structure of demand for migrant labour and the size of the informal economy in Greece, neither the acquisition of legal status nor-more recently—Bulgaria's EU membership appear to have decisively reduced informal employment. With the lack of formal opportunities, migrants developed strategies to cope with being uninsured. One practice - not uncommon among other groups of migrants or native Greeks - was to register with OGA, the insurance fund for agricultural workers. This had less costly contributions, even if workers were not in the agricultural sector. Another strategy, common among domestic workers, was to pay from their own pocket a reduced rate for 'partial' insurance with IKA. It is still uncertain how recent reforms of the Greek national insurance and pension systems will affect the situation of migrant workers in the country.

Employment conditions have mobilized local activists, organizations, and trade unions, including some immigrant workers, in support of migrants' rights. Women in particular have struggled to combine an often harsh working life with motherhood, while they are also vulnerable to sexual harassment from male colleagues and employers. Indicative of the degree of immigrants' exploitation in the Greek labour market is a case that gained wide publicity: the tragic story of a Bulgarian female migrant Konstantina Kuneva (Kambouri and Zavos 2010). A single mother, then 45-years-old, Kuneva worked as a cleaner. She was brutally attacked with sulphuric acid on her way home on 22 December 2008. After months in hospital she recovered, yet suffering partial loss of sight and permanent damage to internal organs. Although the perpetrators remain unknown, they are alleged to have been commissioned by her employers - the cleaning company, OIKOMET - following a history of pressure and threats because of Kuneva's union activism. Her case shocked the public and brought the issues of exploitation of immigrants and employers' brutal treatment of immigrant workers to the forefront of public discourse - becoming the epicentre of struggles for migrants' rights, with campaigns and protests organized in her support. Investigations to bring the perpetrators to justice, however, were remarkably slow and no legal action had been taken, to date.

Kuneva's case may be revealing of the degree of exploitation of migrants in the Greek labour market; yet it also remains exceptional, since union participation among migrants was almost non-existent throughout the 1990s and remains limited (Hatziprokopiou 2006), especially outside the main cities. In an interview, the president of the Rhodes Labour Centre highlighted some additional difficulties in organizing migrant workers in the particular case of small, self-contained economies:

The market is small, the community is small. If you report an employer for unfair treatment, you won't find any other job; the word will spread. Everybody knows everybody. People are scared. Migrants are even more scared. It's better in Athens for organizing (Monastiriotis and Markova 2009, p. 57).

Collective representation has taken other forms instead, focusing on the building of migrant communities - especially after the first regularization in 1998. It was in that year that the first Bulgarian migrant association Vassil Levski was established 
in Athens, with trade union support and hosted by the Athens Labour Centre. Since then, other community organizations have appeared in the capital and across the country (Markova 2001; Hatziprokopiou 2006, pp. 214, 218-219). Indicative of the gradual building of community life are several Bulgarian-language newspapers published in Athens, the first one (Svetlina) starting in 1998. There were at the time of this writing at least three weeklies: Atinski Vesti, Bulgarski Vesti, and Kontakti. There were bimonthly newspapers as well: Planeta, Bulgaria Simera, and Foni tis Bulgarias. ${ }^{11}$ At the same time, private spaces such as cafes and bars in Athens and Thessaloniki, owned or frequented by Bulgarians, became meeting places and local centres of community life (Hatziprokopiou 2006, p. 218; Angelidou 2008). Despite the mushrooming of community organizations and activities, however, individual migrants' active participation may have been decreasing in recent years, as a female interviewee (herself a member of an association) suggested:

Before we were more 'concentrated', we'd gather both with the community, at a cultural level, as well as at a social level, among families. But now it's like everyone is closed to himself, probably because of the crisis.

Two of the longest-established organizations were initially founded by mixed couples (Greeks married to Bulgarians) and attract mainly professionals: the Association of Greco-Bulgarian Friendship (Cyril and Methodius) ${ }^{12}$ in Thessaloniki and the Greek-Bulgarian Association of Mutual Aid and Friendship in Athens. These are perhaps testimony to the trend of inter-ethnic marriages between Bulgarians and Greeks, even before 1989. Official statistics confirm that inter-ethnic partnerships and parenthood constitute a sizeable proportion of families formed by Bulgarians in Greece. ${ }^{13}$ Among a total of 2,453 marriages of Bulgarian women that took place in Greece during 2004-2009, the vast majority (about 80\%) were with Greek nationals. During the same period, 475 marriages took place in Greece involving Bulgarian men, $20 \%$ of whom married women of Greek nationality. Moreover, $30 \%$ of the 2,075 children born to Bulgarian mothers in 2005 and 2006 had Greek fathers. Naturally, family formation in Greece has been developing over the past 20 years or so, and there is already a generation of children born and growing up in the country.

Children appear to be very affected by the emigration of their parents. A study by Guentcheva et al. (2003) reveals high dropout rates from school among children whose migrant parents left them behind in the care of grandparents or other relatives. Such pupils enjoy the freedom of having more money and less parental control than children whose parents did not migrate. Yet many are inclined to start smoking and drinking, eventually quitting school. In the past few years, the Bulgarian press

\footnotetext{
${ }^{11}$ See Eleftherotypia newspaper of 21 February 2008 and the website of the Greek Migrants' Forum (www.migrant.gr).

${ }^{12}$ Saints Cyril and Methodius were Christian missionaries among the Slavic people of the First Bulgarian Empire, Great Moravia, and Pannonia, in the ninth century. They are credited with devising the Glagolic alphabet, used to transcribe Old Church Slavonic.

${ }^{13}$ Data on marriages by nationality of partners, obtained from the Hellenic Statistical Authority, have been kindly provided by Ms D. Papadopoulou (PhD candidate, Middlesex University, UK; elaboration by the authors).
} 
has described these children as having 'Skype parents'. Research on the island of Rhodes reveals that of the nine interviewees who arrived in Greece as minors, only four had completed their education. The rest had primary education only, obtained in Bulgaria. In the meantime, however, most children who followed their parents as dependants, or were born in Greece, have integrated into the Greek school system. Despite immigration restrictions, their acceptance in schools was unconditional of their parents' legal status, even since the 1990s. During the school year 2002-2003, there were 2,873 Bulgarian-born pupils studying in Greek state schools, constituting some $3 \%$ of the total foreign-born pupil population (Baldwin-Edwards 2004a).

In September 2001, the Bulgarian migrant Association Vassil Levski established the first Sunday school for Bulgarian migrant children, teaching in both the Bulgarian and Greek languages. One of its successors managed to get recognition from the Bulgarian Educational System and support from the Bulgarian Embassy in Athens, and increased the number of teachers from two to nine and the range of subjects taught (now including Bulgarian history and geography, as well as folk dancing). This school saw its number of pupils grow from six when it started operating in 2004, to 105 children in 2011. In our interview, its manager reported fluctuations in pupil numbers in line with broader changes in the status and conditions of Bulgarian migrants in Greece, especially in relation to Bulgaria's EU accession and to the unfolding of the crisis in Greece:

After Bulgaria's EU accession, the numbers of pupils dropped.... Then they went up again, especially this year with the economic crisis... parents send them here because they think that as things go bad they may return to Bulgaria... at the end of the year ten families asked for the certificate we issue in order to actually go back.

\subsection{New (and Older) Mobilities: Cross-Border Flows Between Bulgaria and Greece}

As underlined in the introduction, the scope of this chapter is not simply to account for the dynamics of labour migration from Bulgaria to Greece and for the conditions of the Bulgarian migrant population. Indeed, these are situated within a broader context of mobility between the two countries, which involves a diversity of cross-border movements and various types of flows in both directions. Geographical proximity is the primary factor shaping such mobility, which has now entered a new phase following Bulgaria's EU accession. Hence, there has been some degree of political unification of the Greco-Bulgarian space. However, various elements beyond conventional labour migration existed long before 2007. These include migrants' informal practices, which stretch across the borders through social networks linking localities of origin and destination and transnational lifestyles between the two countries - often conditioned by necessity. Practices of this kind might include visits to home villages or towns, whether for holidays or other reasons (Hatziprokopiou 2006, pp. 207-212). Even when travel was not possible, some engagement with the homeland was feasible from a distance - for instance, as far as political participation 
in Bulgaria is concerned. ${ }^{14}$ Moreover, the sending of remittances seems to be declining as migrants build their lives in their places of settlement, as our past studies confirm. Remittances were usually sent through informal channels, such as relatives or compatriots who went back home or by bus companies travelling between the two countries. The funds were provided to support family members left behind, in some cases spouses and/or children. Apart from such 'grassroots' transnational activity, however, our interest here is to investigate empirically quantifiable forms of population movements and other types of mobility, beyond labour migration.

A first type of flow, and perhaps a key structural characteristic of immigration to Greece especially during the 1990s, concerns the relationship between the mobility of labour and that of capital. As explained by Labrianidis and colleagues (2004), at the same time as immigration into Greece intensified in the early 1990s, the country transitioned from being a net receiver of foreign direct investment (FDI) to a net capital exporter. Not only were the Balkans the primary source of migrant labour, but they were also the major destination of Greek FDI, as 'virgin' markets in which large multinationals were initially reluctant to invest. The Balkans offered natural resources, cheap labour, and the possibility to avoid tariff impediments. Most Greek investment projects in the Balkans were concentrated in Bulgaria; the majority were commercial enterprises and industrial plants, with a small but significant presence of service companies (Labrianidis 2000). Up until the early 2000s, many of these projects were undertaken by small and medium-sized enterprises, with or without a parent company in Greece that moved to the Balkans in order to overcome competitiveness problems at home and to reduce labour costs (Labrianidis et al. 2004). This is the same type of company that tends to rely on the employment of immigrants in Greece, reflecting the production structure of the Greek economy. Over the period 1996-2009, Greece was the fourth major investor country in Bulgaria in terms of value, accounting for nearly $8 \%$ of the total. ${ }^{15}$ There are more than 420 Greek businesses in Bulgaria; some $40 \%$ of them were registered after 2000, following almost a decade of Bulgarian migration to Greece (Markova 2010, p. 33). It is worth noting that Bulgarian trade unions speak of highly exploitative conditions in border areas where Greek companies are most active. ${ }^{16}$

Part of this investment has been by the banking sector, as increased transactions by migrants in Greece since the mid-1990s - and their increasing demand for financial services - motivated Greek banks to expand their services in Bulgaria. Legal immigrants remain the main clients, transferring money home. The increased number of Bulgarian migrants legally residing and working in Greece may explain the growing number of Greek bank branches in Bulgaria in the last 10 years. For example, Alpha Bank has now opened branches in over 20 cities in Bulgaria. Five

\footnotetext{
${ }^{14}$ For example, the Macedonian Press Agency reported on 21 October 2001 that about 260 Bulgarians living in Thessaloniki were expected to vote in the Bulgarian national elections on 11 November 2001 at the city's Bulgarian Consulate.

${ }^{15}$ Data from the Bulgarian National Bank reported in the Greek General Secretariat of International Economic Relations and Development Cooperation (www.agora.mfa.gr - thematic category on bilateral agreements).

${ }^{16}$ Interview conducted in April 2009 in Sofia as part of the EU-funded project, Mapping Discrimination in the European Union, Working Lives Research Institute, London Metropolitan University.
} 
large Greek banks - the National Bank of Greece (which owns $99.9 \%$ of the United Bulgarian Bank AD); Piraeus Bank Bulgaria AD; Emporiki Bank-Bulgaria EAD, the merger between Eurobank EFG Bulgaria (Postbank) AD; and Alpha Bank-Bulgaria Branch - currently have a market share of $25-30 \%$ in the country. ${ }^{17}$

There has also been growth in commercial activity between the two countries, with Bulgaria's share in net imports/exports steadily increasing since 1989. Not only are Greek products now manufactured in Bulgaria, but increasingly they are sold to the Bulgarian market as well (Labrianidis 2000; Kamaras 2001). Although Bulgaria remained a secondary trade partner until recently, this seems to be changing with membership of the EU. In 2006, Bulgaria received 6.3\% of total Greek exports in terms of value (in euros); by 2007, this had grown to $6.5 \%$ and Bulgaria was the fourth major buyer of Greek products; in 2008, it became the third major destination, with a share of $7.1 \%$ of total Greek exports. Similarly, imports increased by 0.4 percentage points between 2006 and 2008, and Bulgaria had become the 16th largest supplier of the Greek market by the end of this period. Obviously, Greece's ongoing crisis may interrupt this trend: over the first three quarters of 2009, Greek exports to Bulgaria dropped by about 24 percentage points, and Bulgarian imports decreased by $30 \%$; in the first quarter of 2010 , however, the pace of exports decline was reduced to $6.4 \%$ and imports had registered a slight increase. ${ }^{18}$

Naturally, flows of goods and capital also translate into human mobility. Together with Greek companies, there are movements of Greeks travelling back and forth - merchants and distributors, professionals, bankers, and investors (Hatziprokopiou 2006, p. 254). The Greek presence in Bulgaria and other Balkan countries is so evident that some analysts speak of a 'Greek capitalist diaspora' in the region, constituted by a network of corporate entities and individuals (Kamaras 2001). According to the National Statistical Institute of Bulgaria, among 132,576 people who travelled for business reasons to Bulgaria during January-September 2002, Greeks made up the largest share, approaching $13 \% .^{19} 9$ years later, in 2011, of the 52,434 professionals visiting Bulgaria in January alone, over $40 \%$ were Greeks. Meanwhile, the number of (registered) permanent Greek residents in Bulgaria increased from 814 in 2004 to 964 in 2009. Among them, some may be students following the 'tradition' of young Greeks studying in Bulgaria, even previous to 1989, which may have slowed down but never entirely ceased.

Alongside business travel, there has been an increase in the number of trips for tourism, shopping, and entertainment. According to the Bulgarian National Statistical Institute, an annual average of 806,654 Greeks travelled for various purposes between 2004 and 2009, with the numbers gradually increasing since 2007. For the period January-May 2010, 184,690 Greek visitors travelled for 'holiday and recreation', constituting a share of $22.8 \%$ of foreign tourists in Bulgaria. Some of

\footnotetext{
17 'Invest in Greece' website (pages on investment in Bulgaria): http://www.invgr.com/se_europe. htm

${ }^{18}$ Data are from the Hellenic Statistical Authority as reported by the Ministry of Foreign Affairs (op. cit.)

192002 Data are from Hatziprokopiou (2006, p. 254); 2010 data are available from the Bulgarian National Statistical Institute (www.nsi.bg/index_en.htm).
} 
these movements have been concentrated in the border areas. Back in 2003, Greek TV channels were reporting on Greeks from northern towns or villages, including Thessaloniki, who were visiting places on the other side of the border (e.g., the city of Petrich) for shopping (especially for duty-free goods, at that time still available at the border), but also for other reasons such as gambling in the local casinos, or having low-cost tooth fillings at local dentists (Hatziprokopiou 2006, p. 255). More recently, amidst the Greek economic crisis, during the summer of 2010 the Greek press commented on youths travelling from northern Greece to Bulgaria for live concerts: the combined cost of tickets and travel appeared to be cheaper for them than attending such performances in Athens (with retail petrol prices on the Bulgarian side of the border being about $33 \%$ cheaper than in Greece at the time).$^{20}$ Our interviewee from the Bulgarian/travel agency confirmed this picture, based on her own experience from the business traffic:

We have frequent travellers. There are those who go for business, but also increasingly for tourism, to the ski resorts of Bansko, Borovets, and Pamporovo (UI).

At the same time, an increasing number of Bulgarian tourists travel in the opposite direction. For them, EU accession seems to have marked a shift. The Greek Tourism Organization counted 470,232 arrivals of Bulgarian tourists at the borders in 2002, the seventh most numerous tourist group that year. By 2007, the corresponding figure approached 1.1 million, indicating an unprecedented growth in arrivals of Bulgarians in recent years. Similarly, a sharp growth of their share among the total foreign arrivals at the border was recorded, as depicted in Fig. 10.4. Since 2007, the

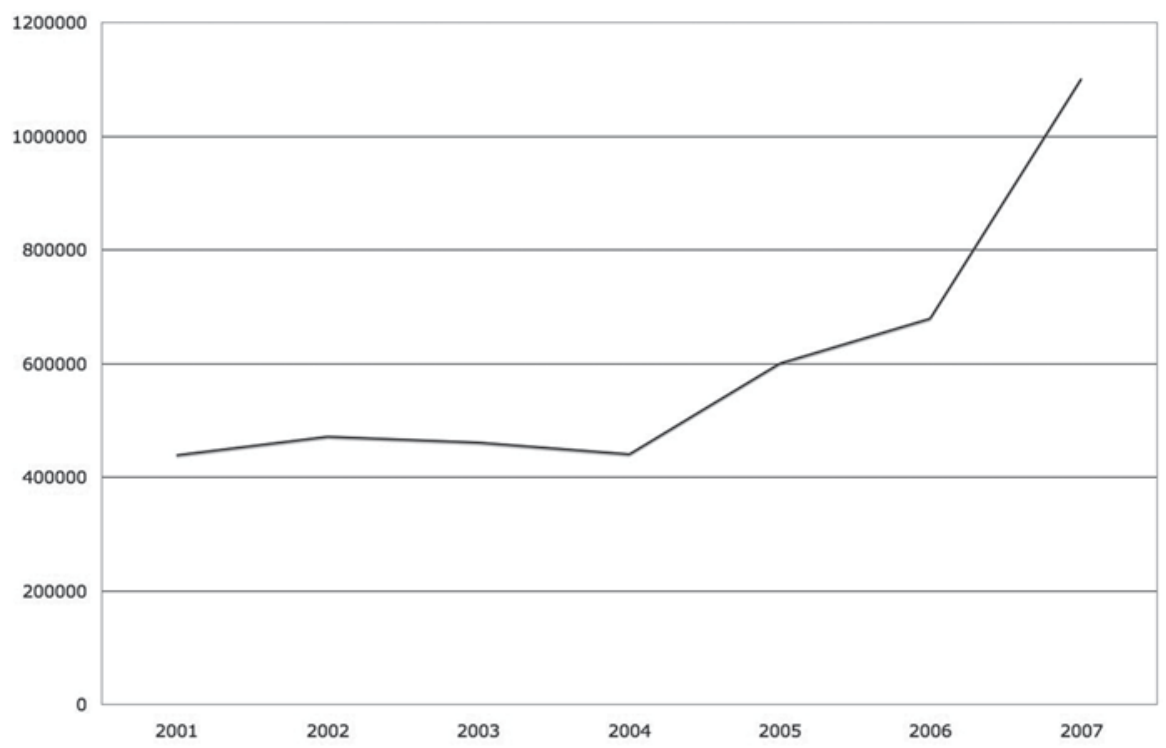

Fig. 10.4 Arrivals of Bulgarians at the Greek border, 2001-2007. (Source: Hellenic Statistical Authority, tourism and border statistics, 2001-2007)

${ }^{20}$ Eleftherotypia newspaper, 1 August 2010. 
Hellenic Statistical Authority has been distinguishing between arrivals of residents and non-residents (based on a sample administered by the Bank of Greece). Even so, the number of Bulgarian visitors remains high. A similar picture is sketched by Bulgarian sources. The number of Bulgarians travelling to Greece has grown steadily over the period 2004-2009 and picked up significantly after 2007, with $1,583,369$ arrivals in 2009. The share of those going to Greece doubled during that period, from $14.4 \%$ in 2004 to $31.7 \%$ in 2009 . Among nearly 1.5 million Bulgarians who had travelled abroad during the first half of 2010 , some $26.4 \%$ were destined for Greece. Of those, $68 \%$ visited Greece for professional reasons, and some $18.1 \%$ as tourists. A local newspaper in Thessaloniki reported that increased numbers of Bulgarian tourists in northern Greece, especially in the areas of Pieria and Kavala, in July 2010, served to compensate for the overall loss of tourist income that summer, in the context of the Greek crisis. ${ }^{21}$

The dark side of tourist movements of Greeks to Bulgaria, especially in border areas, involves a trend of Greek men crossing the border for cheap paid sex. The new dynamics that have emerged on the Greco-Bulgarian border include issues of organized crime, including the smuggling of guns, tobacco, drugs, oil and pirated CDs. ${ }^{22}$ There is also trafficking in people, especially women and minors destined for forced prostitution (IOM 2001). Within this context, the border cities of Petrich and Sandanski in southern Bulgaria have been described as 'the Balkan centres of white slavery' (Emke-Poulopoulos 2001, pp. 15). While in the 1980s most foreign sex workers in Greece were mainly from Asian countries, by the mid-1990s the majority were from Central and Eastern Europe and nearly one third were from the Balkans (Emke-Poulopoulos 2001, p. 4).

This phenomenon forms part of the new mobility dynamics developing along the Greco-Bulgarian border since 1989. Though ethical and political sensitivities remain, in the last 20 years, the emerging cross-border space and border areas themselves have been going though informal processes of economic and societal unification. An interesting example in this respect is the long-discussed Trans-Border Free Industrial Zone of Economic Exchange, which was meant to be established at the Ormenio border area in Thrace, in the town of Trigono, $8 \mathrm{Km}$ away from Edirne (Turkey) and ten from Svilengrad (Bulgaria). Most of the companies planning to move there would have been labour-intensive factories, especially in the clothing sector. An estimated $60-80 \%$ of the workers would commute from Bulgaria on a daily basis (Labrianidis 1998). Long before the plan materialized, the Municipality of Trigono itself, in collaboration with the Bulgarian Municipality of Svilengrad, established a job-finding agency to recruit Bulgarian cross-border workers for agricultural work. ${ }^{23}$ These were expected to compensate for the loss of the local labour force, owing to a trend of young people leaving for the cities. Considering that the majority of internally migrating locals were women, this also resulted in a growing number of men who 'were left without brides' and themselves crossing the border to find a partner. Over the period 2000-2004, some 50 mixed marriages took place

\footnotetext{
${ }^{21}$ Newspaper Aggelioforos of 27 July 2010, article by P. Theodoropoulou, p. 16.

${ }^{22}$ See, for instance, Eleftherotypía, 21 November 2004, article by G. Linardos.

${ }^{23}$ Reported in Eleftherotypía newspaper of 29 December 2004.
} 
between young locals and Bulgarian women from nearby Svilengrad, and 85 children were born. ${ }^{24}$

The case of Trigono is one of many examples of remote border areas in Greece being radically transformed through contact with the 'other side'. Poor and emptied by internal migration and 'forgotten' by the state, they are revitalized economically as well as demographically, in the context of cross-border mobility (see, e.g., Hatziprokopiou 2006, pp. 252-256; see also Deslondes et al. 2008). Even though the 'transborder zone' of Trigono had not materialized in a formal way, numerous informal zones of cross-border contact have spread along the Greco-Bulgarian border in the wake of the restructuring of agrarian systems in both countries, involving constant back-and-forth movements of Bulgarian agricultural workers to the fields of northern Greece (Minev et al. 1997; Darques et al. 2008; Koutsou and Petrou 2008).

\subsection{Conclusion}

The erstwhile impenetrable border of the Iron Curtain that separated Bulgaria and Greece for nearly half a century has now given way to a 'new Greco-Bulgarian border' (Deslondes et al. 2008), easily and frequently crossed for various purposes. This chapter explored primarily labour migration from Bulgaria to Greece, in an attempt to show how this developed over the past 20 years, and to highlight the importance of proximity in conditioning dimensions of transnationalism, cyclical migration, and constant back-and-forth movements. Within this context, the chapter also accounted for other forms of human mobility and other types of flows in both directions. The complex set of processes in place passed through several phases, and the timeline so far has registerd a number of 'milestones' since 1989: the regularization programmes in Greece, the abolition of visa requirements for Bulgarians travelling to the EU, Bulgaria's EU accession, and currently, Greece's economic crisis.

Mobility patterns in Eastern Europe should not simply be seen as a 'flood from East to West', but rather as a 'much wider field of mobility', with the majority of movements being short distance and cross-border (Rogers 2000, p. 10). In the Greco-Bulgarian case, this wider field of mobility suggests not only that the labour markets of Bulgaria and Greece have become increasingly interdependent, as Minev et al. (1997, p. 10) argued more than 15 years ago, and as we also showed in this chapter, but that the entire Greek and Bulgarian societies are increasingly interconnected. The Balkan space, fragmented after years of separate national histories and divided by nationalist conflicts (as the editors recalled in their introduction to this volume), is gradually regaining the unified character it used to have in the years of the Ottoman Empire (Todorova 2009; Mazower 2000). Greece's northern borders opened up in the early 1990s for the first time since World War II. The next step

\footnotetext{
${ }^{24}$ Salimbeni (2004, p. 15) reports on a general trend of migrant women, including Bulgarians, marrying Greek men in the Greek countryside.
} 
in this process took place with the EU accession of Bulgaria and Romania in 2007, which linked Greece by land to the rest of the EU for the first time since it became a member in 1981. Labour migration from Bulgaria to Greece - as well as the multiple types of flows in both directions, relationships, networks, and 'back and forth' movements - are indicative of an evolving cross-border system and a transnational social and economic space, which is shaped by proximity and assumes regional characteristics. After all, the era of globalization is marked by similar integrations at a regional level. The experience of the Balkans post-1989 in particular manifests such expressions of regionalism regarding migration processes (Baldwin-Edwards 2004b).

The cross-border dynamics of labour and capital, and the political economy surrounding them, imply that the character of economic relations between Bulgaria and Greece since the 1990s has been shaped by relations of uneven development and imperialism, dominance, and dependence (Hatziprokopiou 2006; Deslondes et al. 2008), even if Greece is neither the only nor the major player in the area. Economic and other forms of exploitation in both Greece and Bulgaria are at the heart of migration and other forms of mobility. The nature of interdependence between the two countries suggests a cross-border system characterized by a relationship between capital and labour mobility fitting to some degree the analysis of Sassen (1999), whereby - simply put - the latter follows the former and vice-versa (Labrianidis et al. 2004). The micro-level manifestations of this relationship in border areas appear to be analogous, even if on a smaller scale, to the situation characterizing parts of the US-Mexico border, as Deslondes et al. (2008, p. 37) observe.

The Greek state's approach to migration over the past two decades has received extensive criticism for its unrealistic, exclusionary, and repressive logic as far as the control of borders, movement, and people are concerned, as well as for its laissez faire attitude in the labour market, which allowed (certain) employers to benefit in the short run from migrants' exploited employment conditions. With respect to migration from neighbouring countries in particular, one may additionally speak of two decades of lost opportunities to make things easier for the migrants themselves and release substantial potential for development in both Greece and Bulgaria. Cultural and geographic proximity have made possible various forms of mobility, contact, and exchange, which entailed some degree of - and much more potential for-circularity. Realistically managed and with respect for migrants' rights, this could have led to what is described in the literature as a 'triple win' situation, whereby mobility benefits all parties involved - that is, the countries of origin and destination and the migrants themselves (Vertovec 2007; Bieckmann and Muskens 2007). Instead, restrictions on movement, but also on regular stay and employment, have prevented 'full circles' from developing, apart from the limited experience of formal seasonal work and the dynamics in place at border regions. On the other hand, geographical proximity and human need have facilitated various types of flow and bridges built by the human factor. Migrants have been able to support livelihoods between places of origin and destination, establishing new bases for social and cultural contact. Nevertheless, any potential changes that may result from Bulgaria's EU membership and Greece's severe economic difficulties since 2009 are yet to be seen. 
Open Access This chapter is distributed under the terms of the Creative Commons Attribution Noncommercial License, which permits any noncommercial use, distribution, and reproduction in any medium, provided the original author(s) and source are credited.

\section{References}

Angelidou, A. (2008). Migrations in the "neighbourhood": Negotiations of identities and representations about "Greece" and "Europe" among Bulgarian migrants in Athens. Balkanologie: Revue d'études Pluridisciplinaires, 11(1-2). http://balkanologie.revues.org/index1152.html. Accessed 3 Oct 2011.

Bagatelas, W. T., \& Kubicová, J. (2003). Bulgarian emigration: A closer look. South-East Europe Review, 4, 27-35.

Baldwin-Edwards, M. (2004a). Statistical data on immigrants in Greece: An analytical study on available data and recommendations for meeting European Union standards. Report prepared for the Institute for Migration Policy (IMEPO), by the Mediterranean Migration Observatory, Institute for the Urban Environment and Human Resources, Panteion University.

Baldwin-Edwards, M. (2004b). Mediterranean migrations: Regionalisms versus globalisation. Finisterra: Revista Portuguesa de Geografia, 34(77), 9-20.

Baldwin-Edwards, M., \& Apostolatou, K. (2009). Greece. In H. Fassmann, U. Reeger, \& W. Sievers (Eds.), Statistics and reality: Concepts and measurements of migration to Europe (pp. 233262). Amsterdam: Amsterdam University Press.(IMISCOE Reports).

Bieckmann, F., \& Muskens, R. (2007). Circular migration: Creating a vicious circle. The Broker. 22 March. www.thebrokeronline.eu/en/Magazine/articles/Creating-a-virtuous-circle.

Cavounidis, J. (2006). Labor market impact of migration: Employment structures and the case of Greece. International Migration Review, 40(3), 635-660.

Chompalov, I. (2000). Brain drain from Bulgaria before and after the transition to democracy. Paper prepared for the Bulgarian Research Symposium and Network Meeting, Atlanta, GA, 7 April.

Darques, R., Deslondes, O., \& Lory, B. (2008). La disparition du rideau de fer gréco-bulgare: Enquête aux confins de la Macédoine et du Rhodope [The disappearance of the Greek-Bulgarian Iron Curtain: Investigation on the borders of Macedonia and Rhodope]. Méditerranée, 110, $27-35$.

Deslondes, O., Darques, R., \& Lory, B. (2008). La nouvelle frontiere gréco-bulgare. Méditerranée, $110,37-43$

Emke-Poulopoulos, I. (2001). Trafficking in women and children: Greece, a country of destination and transit. Working Paper 2. Athens: Mediterranean Migration Observatory.

Fakiolas, R. (2003). Regularising undocumented immigrants in Greece: Procedures and effects. Journal of Ethnic and Migration Studies, 29(3), 535-561.

Fargues, P. (2008). Circular migration: Is it relevant for the South and East of the Mediterranean? CARIM Analytic and Synthetic Notes, Circular Migration Series: Political \& Social Module 2008/40, Robert Schuman Centre for Advanced Studies. Florence: European University Institute.

Glytsos, N. P. (2010). Theoretical considerations and empirical evidence on brain drain: Grounding the review of Albania's and Bulgaria's experience. International Migration, 48(3), 107-130.

Guentcheva, R., Kabakchieva, P., \& Kolarski, P. (2003). Bulgaria: The social impact of seasonal migration. IOM \& European Commission project. Vienna: International Organization for Migration.

Hatziprokopiou, P. (2004). Balkan immigrants in the Greek city of Thessaloniki: Local processes of incorporation in an international perspective. European Urban and Regional Studies, 11(4), 321-338.

Hatziprokopiou, P. (2006). Globalisation and contemporary immigration to Southern European cities: Social exclusion and incorporation of immigrants in Thessaloniki. Amsterdam: Amsterdam University Press. 
IOM. (2001). Victims of trafficking in the Balkans: A study of trafficking in women and children for sexual exploitation to, through and from the Balkan region. Vienna: International Organisation for Migration.

Kamaras, A. (2001). A capitalist diaspora: The Greeks in the Balkans, The Hellenic Observatory Discussion Paper Series 4. London: London School of Economics and Political Science.

Kambouri, N., \& Zavos, A. (2010). On the frontiers of citizenship: Considering the case of Konstantina Kuneva and the intersections between gender, migration and labour in Greece. Feminist Review, 94, 148-155.

Koutsou, S., \& Petrou, M. (2008). Restructuration des systèmes agraires et perceptions de "l'autre" de part et d'autre de la frontière gréco-bulgare [Restructuring of agricultural systems and perceptions of the "other" on both sides of the Greek-Bulgarian border]. Méditerranée, $110,38-51$.

Labrianidis, L. (1998). I idrysi diasynoriakis eleftheris viomihanikis zonis Oikonomikon Synallagon sto Thraki [The creation of the free cross-border industrial zone of economic exchange in Thrace]. Market Without Borders [Agora Horis Synora], 3(4), 265-280.

Labrianidis, L. (2000). I anasygrotisi ton Valkanion kai o rolos tis Elladas: mia kritiki proseggisi [The restructuring of the Balkans and the role of Greece: A critical approach]. In G. Petrakos (Ed.), The development of the Balkans [I anaptyksi ton Valkanion] (pp. 371-396).Volos: Thessaly University Press \& Gutenberg.

Labrianidis, L., Lyberaki, A., Tinios P., \& Hatziprokopiou P. (2004). Inflow of immigrants and outflow of FDI: Aspects of interdependence between Greece and the Balkans. Journal of Ethnic and Migration Studies, 30(6), 1183-1208.

Markova, E. (2001). Bulgarian migrants' community in Greece. In A. Marvakis, D. Parsanoglou, \& M. Pavlou (Eds.), Migrants in Greece (pp. 247-275). Athens: Elinika Gramata.

Markova, E. (2009). Bulgarian immigration on the island of Rhodes, Greece. Project Report. London: London Metropolitan University: Open Society Institute.Sofia Working Lives Research Institute.

Markova, E. (2010). Legal status and migrant economic performance: The case of Bulgarians in Spain and Greece. In S. Katsikas (Ed.), Bulgaria and Europe: Shifting identities. London: Anthem Press.

Markova, E., \& Black, R. (2007). East European migration and community cohesion. York: Joseph Rowntree Foundation.

Markova, E. M., \& Sarris, A. H. (1997). The performance of Bulgarian illegal immigrants in the Greek labour market. South European Society and Politics, 2(2), 57-77.

Markova, E. M., \& Sarris, A. H. (2002a). Earnings performance of Bulgarian illegal and legalized immigrants in Greece. Discussion Paper 32. Athens: University of Athens, School of Law, Economics and Political Science.

Markova, E. M., \& Sarris, A. H. (2002b). Remitting and saving behaviour of Bulgarian immigrants in Greece. Discussion Paper 34. Athens: University of Athens, School of Law, Economics and Political Science.

Maroukis, T. (2008). Country report: Greece. Report prepared for the project CLANDESTINO, EU 6th Framework Programme. http://irregular-migration.net/typo3_upload/groups/31/4.Background_Information/4.4.Country_Reports/Greece_CountryReport_Clandestino_Nov09_2. pdf. Accessed 26 June 2012.

Maroukis, T., \& Gemi, E. (2010). Circular migration between Albania and Greece. Metoikos Project Report. Robert Schuman Centre for Advanced Studies. Florence: European University Institute.

Mazower, M. (2000). The Balkans. London: Phoenix.

Minev, D., Zheliaskova, M., Ketsetzopoulou, M., \& Bouras, N. (1997). The labour migration from Bulgaria to Greece: Parameters, factors, consequences. Paper presented at the conference NonMilitary Aspects of Security in Southern Europe: Migration, Employment and Labour Markets, Santorini, 19-21 Sept.

Monastiriotis, V., \& Markova, E. (2009). Migrant integration in a small island economy: The case of the island of Rhodes, Greece. London: London School of Economics and Political Science. 
Nikolova, M. (2010). Bulgarians in Greece: Phases and trends. In A. Triandafyllidou \& T. Maroukis (Eds.), Migration in 21st Century Greece (pp. 257-308). Athens: Kritiki.

Rogers, A. (2000). A European space for transnationalism? Transnational Communities Programme Working Paper WPTC-2K-07. ESRC TC Programme, Institute of Social and Cultural Anthropology. Oxford: University of Oxford.

Salimbeni, S. (2004). Marriage migration in Greece. Country Study, DAPHNE Programme-European Commission. Berlin: Berlin Institute for Comparative Social Research.

Sarris, A., \& Markova, E. (2001). The decision to legalize by Bulgarian illegal migrants in Greece. In S. Djajic (Ed.), International migration: Trends, policies and economic impact (pp. 162179). London: Routledge.

SOPEMI. (1993). Trends in international migration. Paris: Organization for Economic Co-operation and Development.

Stanchev, K. (2005). Bulgarian migration: Incentives and constellations. Sofia: Open Society Institute.

Todorova, M. (2009). Imagining the Balkans. New York: Oxford University Press.

Vertovec, S. (2007). Circular migration: The way forward in global policy? International Migration Institute Paper 4. Oxford: University of Oxford.

Panos Hatziprokopiou is Assistant Professor at the Department of Spatial Planning and Development, Aristotle University of Thessaloniki. His research interests focus on aspects of migration and immigrants' integration in Greece, as well as on issues related to difference, diversity and social change in urban contexts. He has published widely on the above topics in peer-reviewed journals and chapters in edited volumes, and is author of the book Globalisation, migration and socio-economic change in contemporary Greece, Amsterdam: Amsterdam University Press, 2006.

Eugenia Markova is Senior Lecturer at the Faculty of Business and Law of London Metropolitan University. She teaches economics and quantitative methods for business. Eugenia has published widely on issues of labour migration, with a focus on undocumented migration, agency work and community cohesion. Her most recent co-authored article 'Migrant Workers in Small London Hotels: Employment, Recruitment and Distribution' is forthcoming in European Urban and Regional Studies and her co-authored book Undocumented workers transitions: Legal status, migration and work in Europe was published by Routledge in 2011. 